\title{
DAMPAK PENGGUNAAN KONTEN YOUTUBE TERHADAP MINAT BELAJAR BAHASA INGGRIS MAHASISWA UNIVERSITAS PAMULANG
}

\author{
Juitania $^{1}$, I Gede Adi Indrawan ${ }^{2}$ \\ S1 Akuntansi, Universitas Pamulang ${ }^{1,2}$ \\ Email: dosen02219@unpam.ac.id ${ }^{1}$,dosen02257@unpam.ac.id ${ }^{2}$
}

\begin{abstract}
Abstrak
Mahasiswa kerap mengalami masalah dalam aktivitas perkuliahannya, salah satu masalah yang dihadapi adalah minat belajar. Minat belajar mahasiswa relatif rendah apabila mempelajari mata kuliah yang dianggap sulit dipelajari, seperti mata kuliah Bahasa Inggris. Minat belajar mahasiswa dapat terbentuk melalui media pembelajaran yang baik dan menarik, semakin menarik media pembelajaran yang akan digunakan maka akan semakin tertarik juga mahasiswa untuk mempelajari materi pembelajaran tersebut. YouTube merupakan media sosial yang kerap digunakan untuk menjadi media pembelajaran. Video tutorial yang berisi beraneka topik pembelajaran banyak diunggah di YouTube dan diminati oleh masyarakat. Video belajar Bahasa Inggris merupakan salah satu video pembelajaran yang terdapat di YouTube, yang dapat diakses oleh seluruh lapisan masyarakat, termasuk oleh mahasiswa. Tujuan dari penelitian ini adalah untuk mengetahui dan menganalisis pengaruh penggunaan konten YouTube sebagai media ajar terhadap minat belajar Bahasa Inggris mahasiswa Program Studi S1 Akuntansi Universitas Pamulang. Metode penelitian yang digunakan berupa statistik deskriptif dan kausalitas. Penelitian kuantitatif dalam melihat hubungan variabel terhadap objek yang diteliti lebih bersifat sebab dan akibat (kausal), sehingga dalam penelitian ada variabel independen dan variabel dependen. Hasil penelitian ini menunjukkan penggunaan konten YouTube sebagai media ajar memiliki pengaruh positif dan signifikan terhadap minat belajar Bahasa Inggris mahasiswa Program Studi S1 Akuntansi Universitas Pamulang.
\end{abstract}

Kata Kunci : Konten Youtube, Minat Belajar, Media Belajar

\begin{abstract}
Students often face many problems in learning process; one of the problem is attentiveness of learning. Students' attention is relatively low when they face difficult subject, such as English. Student attentiveness can be formed by interesting learning media. The more interesting learning media used, the more interested students will be learnt. YouTube is social media that is often used as learning media. The Video tutorials containing various learning topics are widely uploaded on YouTube and the contents are attracted by the public. The English learning video is one of the learning video found on YouTube, which can be accessed by all levels of society, including students. The purpose of this research is to find out and analyze the effect of using YouTube content as teaching media toward students' attentiveness in learning English in Bachelor Degree of Accounting Program in Pamulang University. Descriptive statistics and causality were the method of the research. Quantitative research in looking at variable relationships to the more researched object is the cause and effect (causal), Therefore, in the research, there are independent variable and dependent variable. The result shows the use of YouTube content as teaching media has a positive and significant influence on learning English in undergraduate student of Bachelor Degree of Accounting Program in Pamulang University.
\end{abstract}

Key Words: YouTube content, students' attentiveness, learning media

\section{PENDAHULUAN}

Bahasa merupakan sarana komunikasi yang dapat menyampaikan informasi, ide atau perasaan satu sama lainnya. Bahasa Inggris adalah salah satu bahasa yang digunakan di seluruh dunia. Bahasa Inggris digunakan secara luas, hampir di semua negara menggunakannya baik sebagai bahasa pertama, bahasa kedua ataupun sebagai bahasa asing. Bahasa Inggris telah 
ditetapkan sebagai bahasa internasional, bahasa inggris telah menjadi mata pelajaran penting yang wajib harus dikuasai oleh mahasiswa dan mahasiswi di Indonesia. Dengan ditetapkannya Bahasa Inggris sebagai bahasa Internasional, sebagian besar orang akan berusaha maksimal untuk dapat menguasai Bahasa Inggris agar bisa berkompetisi dalam persaingan internasional karena tidak buta akan informasi dunia. Bahasa Inggris digunakan tidak hanya sebagai penunjang kegiatan pembelajaran tetapi juga sebagai bahasa yang dapat dipergunakan untuk berkomunikasi antar Negara maupun orang asing yang berada di Indonesia.

Menguasai bahasa inggris sebagai alat komunikasi dan penyampaian informasi adalah hal yang penting untuk diaplikasikan ke dalam kehidupan seharihari dan menguasai Bahasa Inggris telah merupakan kebutuhan utama dalam kegiatan berkomunikasi di era globalisasi seperti saat sekarang ini. Seseorang yang menjadikan bahasa inggris adalah bahasa asing mereka akan menggunakan Bahasa Inggris digunakan untuk menunjang kegiatan berkomunikasi dengan penutur Bahasa Inggris lainnya. Mahasiswa dituntut untuk mampu menguasai Bahasa Inggris agar dapat menyerap berbagai informasi karena begitu banyak sumber informasi dengan menggunakan Bahasa Inggris seperti buku, artikel, dan sumber sumber informasi atau pengetahuan lainnya. Hal tersebut membuat Bahasa Inggris perlu untuk dipelajari oleh mahasiswa dan mahasiswi.

Penguasaan bahasa tidak terbatas hanya dapat mengerti apa yang orang lain tuliskan di dalam sebuah artikel atau berbagai sumber informasi tertulis saja, bahasa merupakan sarana yang digunakan dalam berkomunikasi dua arah, komunikasi dapat dilakukan dengan cara menulis dan berbicara. Hal tersebut berarti berkomunikasi dapat berbentuk lisan dan tulisan.

Ada berbagai macam aspek yang harus dipertimbangkan dalam menguasai bahasa inggris adalah penguasaan dalam membuat struktur kalimat dan kekayaan kosakata yang dimiliki oleh para mahasiswa, tanpa penguasaan struktur kalimat Bahasa Inggris yang terorganisir dengan baik dalam menyampaikan pesan melalui bahasa yang komunikatif, baik secara lisan maupun tulisan, bahasa yang tertulis ataupun yang diucapkan akan menjadi kacau dan tidak dapat dimengerti dengan baik oleh lawan bicara jika apa yang disampaikan tidak sesuai dengan strukturnya.

Tingkat keberhasilan dan ketidakberhasilan kegiatan pembelajaran Bahasa Inggris dipengaruhi oleh faktor internal dan faktor eksternal. Faktor internal yang dapat mempengaruhi aktivitas belajar adalah diri mahasiswa itu sendiri seperti keinginan atau minat belajar. Minat tidak dibawa sejak lahir, melainkan diperoleh kemudian karena adanya sesuatu rangsangan keinginan untuk mengetahui sesuatu hal atau objek sebagai wawasan pengetahuan untuk diri mahasiswa secara individu. Minat adalah gejala psikologis yang menunjukkan pemusatan perhatian terhadap suatu objek sebab ada perasaan senang [1]. Minat adalah suatu rasa lebih suka dan rasa keterkaitan pada suatu hal atau aktivitas, tanpa ada yang menyuruh [1].

Minat terhadap sesuatu hal dapat menyokong kegiatan belajar selanjutnya. Adanya minat belajar yang tinggi yang dimiliki mahasiswa maka akan banyak memusatkan perhatiannya pada mata kuliah yang diminatinya daripada mata kuliah lainnya [2]. Pemusatan perhatian yang intensif terhadap suatu materi kuliah itulah memungkinkan ia belajar lebih giat 
dan berprestasi pada bidang tersebut [2]. Minat yang dimiliki tersebut merupakan langkah awal dalam mencapai hasil belajar yang diinginkan [2]. Dengan demikian, mahasiswa yang mempunyai minat belajar yang besar cenderung akan menghasilkan hasil belajar yang memuaskan dan sebaliknya mahasiswa yang mempunyai minat kurang akan menghasilkan hasil belajar yang rendah [2]. Minat belajar yang tidak tinggi serta anggapan bahwa belajar Bahasa Inggris adalah sulit. Hal tersebut merupakan faktor internal yang mempengaruhi sebagian besar mahasiswa dalam melakukan kegiatan belajar. Sedangkan faktor eksternal yang dapat mempengaruhi kegiatan belajar yaitu tenaga pengajar ataupun media pembelajaran baik media pembelajaran konvensional maupun media pembelajaran modern atau media pembelajaran digital.

Internet saat ini telah berkembang dengan pesat sehingga media pembelajaran digital sudah dapat diakses secara mudah, melalui media internet, setiap orang dapat mengakses berbagai informasi yang bermanfaat untuk pengembangan setiap individu. Berbagai informasi yang terdapat di internet dapat dipergunakan untuk bahan belajar sehingga banyak mahasiswa yang tertarik untuk membaca dan mengakses nya. Salah satu media pembelajaran yang dimaksud adalah Youtube. YouTube adalah video online dan yang utama dari kegunaan situs ini ialah sebagai media untuk mencari, melihat dan berbagi konten yang asli ke dan dari segala penjuru dunia melalui suatu web [3]. Materi ataupun pengetahuan tentang Bahasa Inggris tidak hanya ada pada buku teks ataupun website saja tetapi juga ada pada platform Youtube.

YouTube merupakan salah satu bentuk media sosial berbasis video yang mulai naik daun sejak 5 tahun yang lalu. Dilansir dari statistik dalam situsnya sendiri, YouTube memiliki lebih dari satu milyar pengguna yang merupakan hampir sepertiga semua pengguna internet. Hingga Maret 2015, pembuat konten di YouTube sudah mengunggah 10.000 video, karena membuat akun atau channel di YouTube dan meraih pelanggan atau penayangan bisa menghasilkan uang. Lama kelamaan, makin banyak orang membuat akun YouTube yang membuka kesempatan sebagai lapangan pekerjaan. Tiap hari pengguna YouTube bisa menonton ratusan juta jam video dan menghasilkan miliaran kali penayangan. YouTube menjangkau pemirsa rata-rata berusia 18 sampai 34 tahun. Beragam konten video bisa diakses dalam Youtube, mulai dari Musik, Film, Berita dan Informasi, Olahraga, Gaya hidup, Gaming, dan Vlog.

Maraknya konten di media sosial menjadi tontonan rutin para anak muda. Fenomena ini juga muncul dalam kalangan mahasiswa, lebih khususnya mahasiswa semester ganjil Program Studi S1 Akuntansi Universitas Pamulang T.A 2019-2020. Konten yang ada di YouTube sudah menjadi pembicaraan dan tren yang marak digemari oleh para mahasiswa. Hal ini tampak dari penggunaan YouTube di kalangan mahasiswa yang memilih untuk menonton konten yang ada di YouTube secara berkala sesuai dengan jadwal unggahan video para pembuatnya. Selain itu, beberapa mahasiswa juga memiliki akun YouTube dan mengunggah konten mereka sendiri. Bagi sebagian mahasiswa, konten yang ada di Youtube juga dapat digunakan untuk membantu meningkatan pemahaman atas materi perkuliahan yang mereka terima di kelas. Video pembelajaran yang ada pada Youtube merupakan fenomena yang baru bagi para mahasiswa dan peneliti dalam keefektifan pemerolehan kemampuan berbahasa inggris baik bahasa Inggris sebagai bahasa asing maupun bahasa inggris sebagai bahasa kedua di dalam kelas [4]. Menonton video yang bermuatan materi pembelajaran 
menimbulkan adanya minat atau ketertarikan mahasiswa dalam belajar. Minat belajar ini sangat berpengaruh terhadap aktivitas belajar Bahasa Inggris. Minat belajar yang kuat menimbulkan motivasi di dalam diri mahasiswa. Motivasi belajar memiliki tiga fungsi dasar yaitu stimulating function, pointing to the function dan maintaining and regulating function [5]. Ketiga fungsi tersebut saling bersinergi untuk memperkuat keinginan mahasiswa dalam melakukan aktivitas belajar, minat belajar yang tinggi dapat mempengaruhi hasil belajar belajar Bahasa Inggris dari setiap mahasiswa.

Tabel. 1 Hasil Pra-Research Mata Kuliah Tersulit Menurut Mahasiswa S1 Akuntansi Universitas Pamulang T.A 2019-2020

\begin{tabular}{lcc}
\hline Mata Kuliah & Jumlah & Persentase \\
\hline Manajemen Operasional & 27 & $19 \%$ \\
Akuntansi Internasional & 24 & $16 \%$ \\
$\begin{array}{l}\text { Perpajakan } \\
\text { Pengantar } \quad \text { Aplikasi }\end{array}$ & 26 & $17 \%$ \\
Komputer & 23 & $15 \%$ \\
Bahasa Inggris & 50 & $33 \%$ \\
Total & 150 & $100 \%$ \\
\hline
\end{tabular}

Hasil praresearch yang dilakukan di Program Studi S1 Akuntansi terhadap 150 orang mahasiswa menunjukkan bahwa dari beberapa mata kuliah yang dipelajari, mata kuliah Bahasa Inggris menjadi mata kuliah yang paling sulit untuk dipahami oleh sebagian besar mahasiswa. Untuk mengatasi kesulitan tersebut, sebagian besar mahasiswa memanfaatkan konten YouTube terutama yang berisikan materi pembelajaran Bahasa Inggris untuk membantu mereka memahami materi perkuliahan yang sebelumnya mereka terima di kelas.

Penelitian yang dilakukan sebelumnya berjudul Pengaruh Minat Belajar Mahasiswa dan Persepsi Mahasiswa Tentang Keterampilan Mengajar Dosen Terhadap Motivasi Belajar Pada Mata
Kuliah Teori Akuntansi FKIP UMS Angkatan Tahun 2013 [6], mengungkapkan hasil pada Program Studi Pendidikan Akuntansi FKIP UMS yaitu minat belajar mahasiswa dan persepsi mahasiswa tentang keterampilan mengajar dosen berpengaruh positif terhadap motivasi belajar teori akuntansi FKIP UMS tahun angkatan 2013 sebesar 72,4\% ( $\left.\mathrm{R}^{2}\right)$.

Pada penelitian sebelumnya yang berjudul Pemanfaatan YouTube Sebagai Media Ajar dalam Meningkatkan Minat dan Motivasi Belajar [7], mengungkapkan hasil mahasiswa sangat setuju dengan pemanfaatan Youtube sebagai media ajar dalam belajar Public Speaking. Youtube digunakan mahasiswa sebagai sarana mencari informasi, berita dan hiburan. Youtube juga digunakan untuk saling berbagi video. Mahasiswa di dalam kelas Public Speaking secara individu maupun kelompok diberikan tugas untuk merekam tugas seperti pidato dan mc yang dilaksanakan di kelas, kemudian hasil rekaman ditugaskan untuk diunggah pada YouTube.

Identifikasi masalah berdasarkan penjabaran sebelumnya dapat dirumuskan sebagai berikut: Apakah minat belajar Bahasa Inggris mahasiswa semester ganjil Program Studi S1 Akuntansi Universitas Pamulang T.A 2019-2020 dipengaruhi oleh konten YouTube. Penelitian ini bertujuan untuk membuktikan dan menganalisis pengaruh konten YouTube terhadap minat belajar Bahasa Inggris mahasiswa semester ganjil Program Studi S1 Akuntansi Universitas Pamulang T.A 2019-2020. Adapun kerangka pemikiran dalam penelitian ini adalah sebagai berikut:

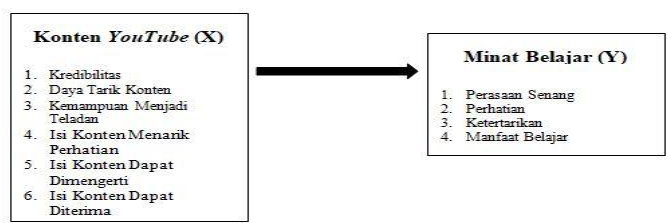

Gambar 1. Diagram Penelitian 


\section{METODE}

Penelitian ini tergolong dalam penelitian kuantitatif. Analisis data yang digunakan dalam penelitian ini berupa statistik deskriptif dan kausalitas. Pada penelitian kuantitatif dalam melihat hubungan variabel terhadap objek yag diteliti lebih bersifat sebab dan akibat (kausal), sehingga dalam penelitiannya ada variabel independen dan variabel dependen [8].

Penelitian ini bertujuan untuk menjelaskan aspek-aspek yang relevan dengan fenomena yang diamati dengan mendeskripsikan gambaran pengaruh antara konten YouTube terhadap minat belajar Bahasa Inggris pada mahasiswa semester ganjil Program Studi S1 Akuntansi Universitas Pamulang T.A 2019/2020 melalui kegiatan observasi, serta kuesioner yang dilanjutkan dengan uji validitas, uji reliabilitas, uji asumsi klasik (uji multikolinearitas, uji normalitas, dan uji heterokedastisitas), dan uji regresi linear berganda dengan menggunakan SPSS versi. 20.

Variabel penelitian berdasarkan kerangka pemikiran yang penulis tuliskan pada penelitian ini, dapat terlihat adanya dua variabel utama penelitian yang akan dijabarkan sebagai berikut:

Variabel $X$ (Independent Variable): Konten YouTube

Variabel Y (Dependent Variable): Minat Belajar Bahasa Inggris

Populasi dari penelitian ini adalah seluruh mahasiswa semester ganjil Program Studi S1 Akuntansi Universitas Pamulang T.A 2019/2020 yang mendapatkan perkuliahan Bahasa Inggris berjumlah 2.500 orang. Teknik sampling yang digunakan di dalam penelitian ini yaitu teknik pengambilan sampel probabilitas dengan mengunakan rumus slovin sebagai berikut :

$$
n=\frac{N}{1+N\left(e^{2}\right)}
$$

Hasil perhitungan dengan menggunakan rumus Slovin didapatkan hasil sebesar 345. Hasil tersebut berarti jumlah sampel yang ditetapkan adalah sebanyak 345 responden. Sasaran responden adalah seluruh mahasiswa semester ganjil Program Studi S1 Akuntansi Universitas Pamulang T.A 2019/2020 yang mendapatkan perkuliahan Bahasa Inggris.

Penelitian ini menggunakan sebuah kuesioner yang disusun dengan menggunakan skala likert jenjang lima. Sejumlah pernyataan disusun dengan jawaban responden yang berada dalam satu kontinum antara sangat setuju dan sangat tidak setuju.

Tabel 2. Skala Likert Pengukuran Instrumen

\begin{tabular}{cc}
\hline Interval Koefisiensi & Tingkat Hubungan \\
\hline $0,00-0,199$ & Sangat Rendah \\
$0,20-0,399$ & Rendah \\
$0,4-0,599$ & Sedang \\
$0,6-0,799$ & Tinggi \\
$0,8-1,00$ & Sangat Tinggi \\
\hline
\end{tabular}

Hipotesis dalam penelitian ini adalah:

$\mathrm{H}_{0}$ : Konten YouTube tidak memiliki pengaruh positif terhadap minat belajar Bahasa Inggris.

$\mathrm{H}_{1}$ : Konten YouTube memiliki pengaruh positif terhadap minat belajar Bahasa Inggris.

\section{HASIL DAN PEMBAHASAN}

Hasil Uji Validitas dan Reliabilitas Instrumen Penelitian

Validitas menunjukkan sejauh mana suatu alat ukur itu mengukur apa yang ingin diukur. Metode pendekatan korelasi product moment digunakan dalam pengujian validitas instrumen dengan ketentuan suatu instrumen dapat dinyatakan valid apabila nilai $r_{\text {hitung }}>$ nilai $r_{\text {tabel }}$ pada $N=345$. Hasil penghitungan 
terlihat semua item pernyataan dalam kuesioner sudah memenuhi syarat valid, yaitu nilai $r_{\text {hitung }}>r_{\text {tabel }}$ dan Sig. $<0,05$, sehingga dapat disimpulkan bahwa instrumen yang digunakan dapat dilanjutkan membahas permasalahan dalam penelitian ini.

Uji reliabilitas digunakan untuk mengukur ketepatan suatu instrumen, suatu instrumen pengukuran dikatakan reliabel bila memberikan hasil score yang konsisten pada setiap pengukuran. Metode rumus korelasi Alpha Cronbach digunakan dalam pengujian reliabilitas instrumen dengan ketentuan nilai Alpha Cronbach > 0,6. Hasil penghitungan terlihat bahwa semua variabel penelitian ini dinyatakan reliabel. Dengan demikian, data yang dipergunakan telah layak digunakan pada analisis berikutnya.

Tabel 3. Hasil Uji Reliabilitas Variabel Penelitian

\begin{tabular}{ccc}
\hline Variabel & $\begin{array}{c}\text { Alpha } \\
\text { Croncbach } \\
\text {-Hitung }\end{array}$ & Keputusan \\
\hline Konten & 0,956 & $\begin{array}{l}\text { Reliabel Alpha } \\
\text { Cronbach pada } \\
\text { YouTube }\end{array}$ \\
Minat Belajar & 0,935 & $\begin{array}{l}\text { Masing-Masing } \\
\text { Variabel }>0,60\end{array}$ \\
\hline
\end{tabular}

\section{Hasil Uji Asumsi Klasik}

\section{Uji Normalitas}

Uji normalitas digunakan untuk menguji apakah suatu model regresi, residual terdistribusi secara normal. Kriteria normalitas dapat diketahui dengan cara melihat probability plot yang dapat membandingkan antara distribusi kumulatif dari distribusi normal. Distribusi normal akan membentuk satu garis lurus diagonal, dan plotting data residual akan dibandingkan dengan residualnya. Distribusi data residual dapat dikatakan terdistribusi normal maka garis yang menggambarkan data sesungguhnya akan mengikuti garis diagonalnya.

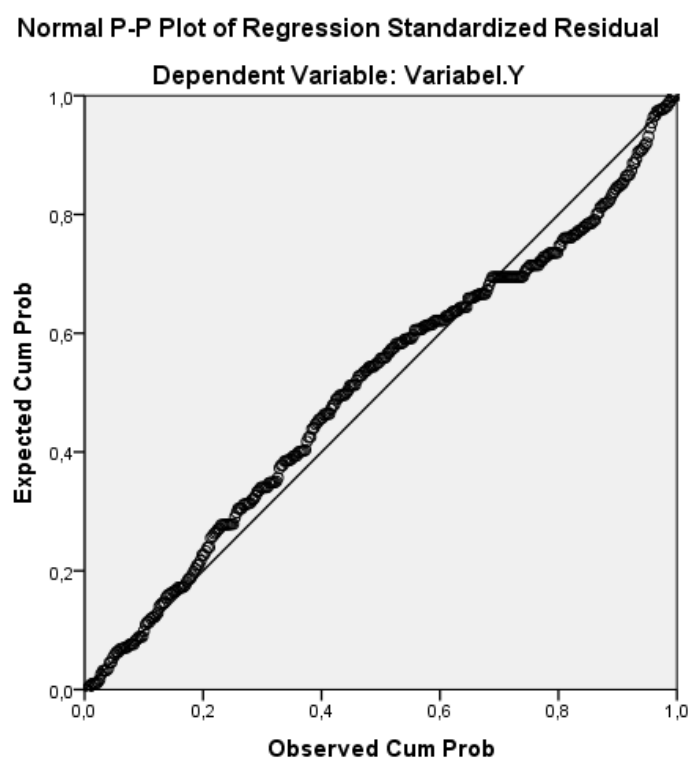

\section{Gambar 2. Grafik P-Plot Normalitas}

Gambar 1. menggambarkan bahwa data penelitian dalam model regresi terdistribusi secara normal. Distribusi normal ini dapat dilihat melalui garis yang menggambarkan data sesungguhnya mengikuti garis diagonal. Gambar tersebut mengartikan bahwa sebaran data dikatakan tersebar disekeliling garis lurus (tidak terpencar jauh dari garis lurus), sehingga normalitas terpenuhi. Model regresi berdasarkan pengujian ini dapat dikatakan terdistribusi normal dan bisa dilanjutkan ke tahap pengujian selanjutnya.

\section{Uji Multikoliniearitas}

Uji multikolinearitas digunakan untuk melihat hubungan korelasi antar variabel bebas, model regresi yang baik seharusnya tidak terjadi korelasi di antara variabelvariabel independen, jika variabel-variabel independen saling berkorelasi maka variabel-variabel tidak ortogonan. Variabel ortogonan adalah variabel independen yang nilai korelasi antar sesama variabel independen sama dengan nol. Uji multikolinearitas dapat diketahui dari tabel coefficients hasil regresi atas variabel konten YouTube $(X)$, 
terhadap variabel minat belajar $(Y)$, seperti tertera di tabel berikut :

Tabel 4. Hasil Uji Multikolinearitas

\begin{tabular}{ccc}
\hline Variabel & Tolerance & VIF \\
\hline $\begin{array}{c}\text { Konten } \\
\text { YouTube } \\
(\text { Variabel } X)\end{array}$ & 1,000 & 1,000 \\
\hline
\end{tabular}

Data penelitian pada Tabel 4 dapat dikatakan tidak menunjukkan suatu gejala multikolinearitas apabila nilai VIF $<10,00$ dan memiliki nilai tolerance $>0,10$. Tabel 5.12. menunjukkan variabel konten YouTube $(X)$ memiliki besaran nilai VIF $1,000<10,00$ dan nilai tolerance $1,000>$ 0,10 terhadap variabel minat belajar $(Y)$, maka dapat dikatakan variabel konten YouTube tidak terjadi gejala multikolinearitas.

\section{Uji Heterokedastisitas}

Uji heterokedastisitas digunakan untuk dapat mengetahui ada atau tidaknya heterokedastisitas, salah satunya dengan menggunakan grafik plot antara nilai terikat dengan residualnya. Uji heterokedastisitas digunakan untuk menunjukkan nilai varians $(Y-Y)$ antar nilai $Y$ tidak konstant atau sama dari satu pengamatan ke pengamatan yang lainnya. Gejala heterokedastisitas dapat diketahui dengan melihat diagram pancar, apabila diagram pancar yang ada membentuk suatu pola tertentu yang teratur maka regresi memiliki gangguan heterokedastisitas. Model regresi dapat dikatakan tidak mengalami suatu gangguan heterokedastisitas jika diagram pancar membentuk pola acak. Gambar 2 di bawah ini menunjukkan diagram pancar tidak membentuk pola tertentu atau acak menyebar di atas dan di bawah angka 0 pada sumbu $Y$, sehingga bisa dinyatakan bahwa regresi tidak terjadi gangguan heterokedastisitas.

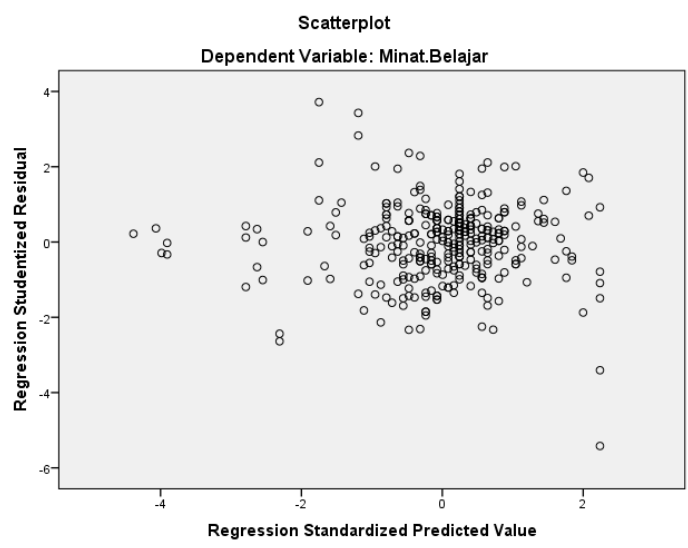

Gambar 3. Grafik Plot Heterokedastisitas

\section{Analisis Regresi Berganda}

Penggunaan analisis regresi linier berganda dalam penelitian ini akan memperlihatkan apakah konten YouTube berpengaruh terhadap minat belajar. Hasil pengujian regresi linier berganda terangkum dalam Tabel 5.

Tabel 5. Hasil Analisis Regresi Linear

\begin{tabular}{ccccc}
\hline Variabel & $\begin{array}{c}\text { Koefisien } \\
\text { Regresi }\end{array}$ & Beta & $\boldsymbol{t}$ & Sig \\
\hline $\begin{array}{c}\text { Konstanta } \\
\text { Konten }\end{array}$ & 55,179 & & & \\
YouTube $(X)$ & 0,397 & 0,445 & 9,212 & 0,000 \\
$F_{\text {hitung }}=84,865$ & & & & \\
$R^{2}=0,198$ & & & & \\
\hline
\end{tabular}

Merujuk pada Tabel 5. didapat model persamaan regresi sebagai berikut:

$Y=55,179+0,397 X$

\section{Koefisien Determinasi ( $R$-Square)}

Tabel 5. menunjukkan hasil analisis data dengan menggunakan alat bantu SPSS diperoleh nilai koefisien determinasi $\left(R^{2}\right)$ sebesar 0,198. Koefisien tersebut mendefinisikan bahwa sumbangan relatif yang diberikan oleh kombinasi variabel konten YouTube $(X)$ terhadap variabel minat belajar $(Y)$ sebesar $19 \%$ sedangkan variabel lain yang tidak diteliti mempengaruhi sisanya. 
Dampak penggunaan Konten Youtube sebagai Media Ajar terhadap Minat Belajar Bahasa Inggris Mahasiswa Program Studi S1 Akuntansi Dengan melihat Tabel 5, dilakukan pengujian statistik hasil analisis regresi linear sebagai berikut:

$H_{0}$ : ry.xl $=0, H_{0}$ : Konten YouTube tidak memiliki pengaruh positif terhadap minat belajar Bahasa Inggris.

$H_{1}$ : ry.xl $\neq 0, H_{1}$ : Konten YouTube memiliki pengaruh positif terhadap minat belajar Bahasa Inggris.

Penelitian mendapatkan hasil $t_{\text {hitung }}$ adalah sebesar 9,212. Hasil $t_{\text {tabel }}$ dengan tingkat signifikansi sebesar 0,05 adalah $t_{\text {tabel }} 1,645$ dan hasil $t_{\text {tabel }}$ dengan tingkat signifikansi 0,01 adalah $t_{\text {tabel }} 2,326$. Berdasarkan hasil yang didapat dari perhitungan statistik pada $t_{\text {hitung }}$ dan $t_{\text {tabel }}$ dengan tingkat signifikan 0,05 dan 0,01 dapat disimpulkan bahwa $t_{\text {hitung }}$ lebih besar dari pada $t_{\text {tabel }}$ $(9,212>1,645>2,326)$. Jadi $H_{0}$ ditolak dan $H_{1}$ diterima, hal tersebut menunjukkan bahwa dampak penggunaan konten youtube memiliki pengaruh postif terhadap minat belajar Bahasa Inggris mahasiswa program studi S1 Akuntansi. Hasil temuan sejalan dengan penelitian sebelumnya, yang menyatakan pemanfaatan konten YouTube sebagai media ajar berperan secara signifikan terhadap minat belajar mahasiswa [7]. Artinya adalah jika pemanfaatan konten YouTube menurun maka minat belajar Bahasa Inggris juga akan menurun. Berdasarkan teori kognitif pada multimedia learning theory memberikan penjelasan dalam kegiatan pembelajaran atau kegiatan belajar mengajar adalah melalui video yang dapat membantu para mahasiswa untuk belajar lebih baik. Teori tersebut menyarankan bahwa menjelaskan informasi dalam format video dapat mengakomodir indra penglihatan dan juga indra pendengaran, metode tersebut lebih efektif dalam kegiatan pembelajaran dibandingkan hanya mengakomodir salah satu indra saja [4].

Penggunaan konten Youtube sebagai sarana kegiatan pembelajaran yang sangat menarik sehingga menimbulkan suasana belajar yang nyaman yang dapat menimbulkan minat belajar bahasa inggris Hal ini didukung oleh hasil penelitian yang dilakukan oleh Alimemaj yang menyatakan bahwa Konten Youtube menimbulkan minat belajar mahasiswa baik dari dalam diri maupun dari ekternal diri mahasiswa karena teknologi tersebut sangat dekat dengan budaya pada masa kini [9]. Penggunaan konten Youtube dipilih sebagai media ajar yang terbaik dalam memfasilitasi kegiatan belajar mahasiswa dalam belajar berbagai macam materi atau topik pembahasan bahasa Inggris secara audio visual sehingga semua gaya belajar mahasiswa dapat terakomodir dengan baik, tidak hanya gaya belajar saja yang dapat terakomodir dengan baik tetapi juga mahasiswa dapat terlibat langsung pada kegiatan berdiskusi, dan berinteraksi seperti menulis catatan penting dari setiap materi yang sedang dipelajari, mencari kata-kata sulit yang ditemui pada saat menonton video, memiliki keinginan untuk membaca atau mencari materi lainnya yang berkaitan dengan video atau konten youtube yang sedang digunakan sebagai media belajar. Hal tersebut memperkuat konten Youtube digunakan sebagai media ajar bahasa Inggris menimbulkan minat belajar yang tinggi sehingga mahasiswa senang belajar bahasa inggris yang akan berdampak pada hasil belajar bahasa Inggris.

\section{SIMPULAN}

Peneliti menyimpulkan bahwa dampak pemanfaatan konten YouTube sebagai media ajar memiliki pengaruh positif terhadap minat belajar bahasa Inggris mahasiswa program studi S1 Akuntansi Universitas Pamulang. Hal tersebut dapat 
dilihat pada hasil perhitungan $t_{\text {hitung }} 9,212$ lebih besar dari $t_{\text {tabel }}$; dengan level signifikansi 0,05 adalah sebesar 1,645 dan dengan level signifikansi 0,01 adalah sebesar 2,236 oleh karena itu $H_{1}$ diterima. Hal tersebut menunjukkan bahwa mahasiswa dapat lebih cepat menerima materi atau topik pembelajaran yang ada pada konten-konten YouTube sebagai media ajar bahasa Inggris. Melalui konten yang menarik yang dilengkapi dengan audio visual sehingga mahasiswa dapat dengan mudah menyerap dan memahami materi atau topik yang dipelajari.

\section{DAFTAR PUSTAKA}

[1] A. Andriana. "Pengaruh Lingkungan Sekolah Terhadap Minat Belajar Siswa Kelas XI MA Wasiltul Falah Rangkasbitung”, vol. 91, no. 5. 2012.

[2] D. W. Utami, "Hubungan Minat Belajar Mahasiswa terhadap Hasil Belajar pada Mata Kuliah Sosiologi Antropologi di Program Studi Pendidikan IPS FITK UIN Syarif Hidayatullah Jakarta”. hal 140, 2014.

[3] S. H. Eribka Ruthellia, D. M. Sondakh. "Pengaruh Konten Vlog dalam Youtube terhadap Pembentukan Sikap Mahasiswa Ilmu Komunikasi Fakultas Ilmu Sosial dan Politik Universitas Sam Ratulangi". Acta Diurna, vol. 6, no. 1, p. 93363, 2017, [Online]. Available: https://www.neliti.com/publications/9 3363/pengaruh-konten-vlog-dalamyoutube-terhadap-pembentukan-sikapmahasiswa-ilmu-kom.

[4] T. E. Raniah Kabooha. "The Effects of YouTube in Multimedia Instruction for Vocabulary Learning: Perceptions of EFL Students and Teachers". English Lang. Teach., vol. 11, no. 2, p. 72, 2018, doi: 10.5539/elt.v11n2p72.

[5] L. C. Chunmei Long, Zhu Ming. "The Study of Student Motivation on English Learning in Junior Middle School -- A Case Study of No.5
Middle School in Gejiu". English Lang. Teach., vol. 6, no. 9, pp. 136145, 2013, doi: 10.5539/elt.v6n9p136.

[6] G. F. Yahya. "Pengaruh Minat Belajar Mahasiswa dan Persepsi Mahasiswa tentang Keterampilan Mengajar Dosen terhadap Motivasi Belajar pada Mata Kuliah Teori Akuntansi FKIP UMS Angkatan Tahun 2013". IOSR J. Econ. Financ., vol. 3, no. 1, p. 56, 2016, doi: https://doi.org/10.3929/ethz-b000238666.

[7] H. Mujianto. "Pemanfaatan Youtube Sebagai Media Ajar dalam Meningkatkan Minat dan Motivasi Belajar". J. Komun. Has. Pemikir. dan Penelit., vol. 5, no. 1, pp. 135-159, 2019.

[8] M. A. A. Andi Ibrahim, Asrul Haq Alang, Madi, Baharuddin dan Darmawati. "Metodologi Penelitian". J. Petrol., vol. 369, no. 1, pp. 16891699, 2013, doi: 10.1017/CBO9781107415324.004.

[9] T. E. Raniah Kabooha. "The Impacts of Using YouTube Videos on Learning Vocabulary in Saudi EFL Classroom". ICERI2015 Conf., pp. 3525-3531, 2015, [Online]. Available: https://www.researchgate.net/publicati on/283153582_THE_IMPACTS_OF_ USING_YOUTUBE_VIDEOS_ON_L EARNING_VOCABULARY_IN_SA UDI_EFL_CLASSROOMS. 